DOI: $10.26693 / \mathrm{jmbs05.04.110}$

UDC 616. 314: 575. 16: 616 - 092. 4

Cheshko N. N.

\title{
THE EFFECT OF LOW DOSES OF IONIZING RADIATION ON ODONTOGENESIS IN FETAL RATS
}

\author{
Belarusian State Medical University, Department of Oral Surgery, \\ Minsk, Republic of Belarus
}

ip-c@yandex.ru

The purpose of the study was to establish the effect of low doses of ionizing radiation on the structure of tooth germs in ontogenesis and to identify the nature of possible changes.

Material and methods. The experiments were carried out on albino rats mongrel gregarious breeding. Gravid female rats were exposed to chronic irradiation on "Gammarid 192/120 unit» at $110 \mathrm{mR} / \mathrm{h}$ power of exposition for 16 days at the Institute of Radiobiology of the National Academy of Sciences of the Republic of Belarus. The total dose absorbed by the fetuses was 0.38 Gy.

Another group of gravid female rats (control) was housed in standard vivarium conditions. The controls were not irradiated. Gravid female rats were sacrificed by decapitation under chloroform anesthesia. Rats' fetuses were extirpated from the uterus and were decapitated.

The material was fixed in $10 \%$ neutral formalin and embedded in paraffin by standard methodology. Sagittal «serial-selective» sections were stained with hematoxylin and eosin, picrofuchsin after van Gieson sum content of DNA and RNA, which was evaluated by 5 -mark scale, revealed by the method of Einarson, elastic fibers (Hart), argyrophil ones (Bilshovsky in G. Berlov's modification).

Proliferative activity was determined according to the method of I. A. Kazantseva. The number of cellular layers was also counted. Using the image analysis system "Bioscan-AT", the area and thickness of the structures of tooth germs were determined by contour measurements.

Results and discussion. Low doses of ionizing radiation did not interfere with the genetically determined odontogenesis process in 16-day-old fetal rats, but they significantly reduced the proliferative activity of the cells. Chronic irradiation caused 3 times decrease in the mitotic activity of tooth germs in 16-dayold fetal rats. This, in turn, resulted in the decrease in the size, number of cell layers, shape change, delay and impairment of tooth germ differentiation, lack of "concentric structures", their description hasn't been found in the literature.
Conclusion. Thus, small doses of ionizing radiation did not violate the genetically programmed course of odontogenesis, but caused a number of changes that can play a negative role in the further stages of dental development and in the postnatal period.

Keywords: odontogenesis, ionizing radiation, low doses, rat.

Introduction. In radiobiology, the concept of "low doses" is associated with the dose at which the effects under investigation begin to appear [1]. For all this, the upper limit of "low doses" is determined in different ways, depending on the evaluation criterion. When studying the effect of ionizing radiation on organisms, low doses" are those that do not cause noticeable disturbances in vital activity. Based on this, some authors suggest to count for "low doses" of a person in the range up to $200 \mathrm{mGy}$ and $500 \mathrm{mGy}$ for mammals [2].

Experiments studying the effects of ionizing radiation in large doses on biological systems have shown its damaging effect. Irradiation of mammalian fetuses caused their prenatal or postnatal death and numerous anomalies. We have found only a few reports about the effects of ionizing radiation on the tooth tissue in utero but no articles about the effect of low doses of ionizing radiation on tooth germs. To date, a lot of material has been accumulated, mainly on the effects of high doses of ionizing radiation, and in dentistry [3]. Published data is incomplete and often contradictory. For example, some researchers consider pre- and odontoblasts to be more sensitive to ionizing radiation $[4,5]$, while others consider ameloblasts to be more sensitive [6]. There is almost no information about the proliferative activity of dental germ cells, this is not mentioned even in the extensive guidelines on histology and embryology [7, 8], or generalized numbers are provided, regardless of a particular cell type [9]. Without answers to these and other questions, it is difficult to assess the morphological effects of ionizing radiation.

The purpose of our research was to establish the effect of low doses of ionizing radiation on the 
structure of tooth germs in ontogenesis and to identify the nature of possible changes.

Material and methods. The study was carried out on albino rats mongrel gregarious breeding with the initial weight $0.16-0.18 \mathrm{~kg}$. Experimental female rats (4 months old) in the stage of estrus were placed to males in the ratio $3: 1$. The first day of gestation was determined by the presence of sperm in vaginal smears.

One group of gravid female rats was exposed to chronic irradiation on "Gammarid 192/120 unit" at $110 \mathrm{mR} / \mathrm{h}$ power of exposition for 16 days at the Institute of Radiobiology of the National Academy of Sciences of the Republic of Belarus (Gamma-defectoscope "Gammarid" manufactured by the "Isotop" Enterprise, Leningrad). The total dose absorbed by the fetuses was $0.38 \mathrm{~Gy}$.

Another group of gravid female rats (control) was housed in standard vivarium conditions. The controls were not irradiated. All animals were fed in accordance with the established norms. Gravid female rats were sacrificed by decapitation under chloroform anesthesia. Rats' fetuses were extirpated from the uterus and were decapitated.

The material was fixed in $10 \%$ neutral formalin and embedded in paraffin by standard methodology. Sagittal «serial-selective» sections [10] were stained with hematoxylin and eosin, picrofuchsin after van Gieson sum content of DNA and RNA, which was evaluated by 5-mark scale, revealed by the method of Einarson, elastic fibers - by Hart, argyrophil ones - by Bilshovsky (G. Berlov's modification) [11].

Proliferative activity was determined according to the method of I. A. Kazantseva [12]. The number of cellular layers was also counted. The square, thickness and length of TG were measured with "Bioscan AT" automatic image analyser (Model was constructed in Central Scientific-Research Laboratory, Medical Institute, Minsk) [13]. The measurements were carried in each case of control and experiment 10 times as minimum. On the whole 327 histologic specimens were studied. The data were analyzed by variation statistics with the Student's test.

All animal experiments were performed according to international principles "of the European Convention for the Protection of vertebrate animals used for experimental and other scientific purposes" (Strasbourg, 18.03.1986).

Statistical processing of quantitative data was performed using the Statistica 6.0 application software package. The average value (M) and the average error $(m)$ were calculated. The results of the study are presented in the form of $\mathrm{M} \pm \mathrm{m}$ values. When comparing groups, the Student's parametric criterion was used. The differences were considered statistically significant at $p<0.05$ [14].
Results and discussion. Control fetuses had dental lamina formed by several layers of epithelial cell of cuboidal or polygonal shape with poor, intensively stained cytoplasm, large-sized nuclei with dense fine-grained chromatin and a single small punctate nucleolus. The latter wasn't detected in many nuclei. The borders of the cells were difficult to differentiate. Nuclei looked adjoined one another. At the basement membrane, this epithelial layer was bordered by high prismatic cells with the same tinctorial properties. They were arranged denser than the surface layers cells some of which had clearer spaces between them. Due to these spaces the cell body shape was more clearly outlined. Mitoses were frequently observed, sometimes 3-4 per one binocular visual field (x200). In the dental lamina spherical accumulations of epithelial cells occurred; they formed layers on each other and slightly reminded sectioned onions - "concentric structures" that frequently were located on the basement membrane.

In the experimental animals the dental lamina was sharply and irregularly thinned here and there to a single layer of condensed slightly atrophic epithelial cells. The number of layers in it was 2.67 times lower than those in the control: $2.00 \pm 0.23$ and $5.33 \pm 0.42$, respectively $(p<0.001)$. The above mentioned "concentric structures" were not found in any of 171 serial sections. Here and there the cells of mesenchyme destroyed the basement membrane and dental lamina and extended into the oral cavity. More often dental buds protruded out from the dental lamina, invaginating it only in a few cases (Fig. 1). Tooth buds, especially extended into the oral cavity ones were not found in the control group.

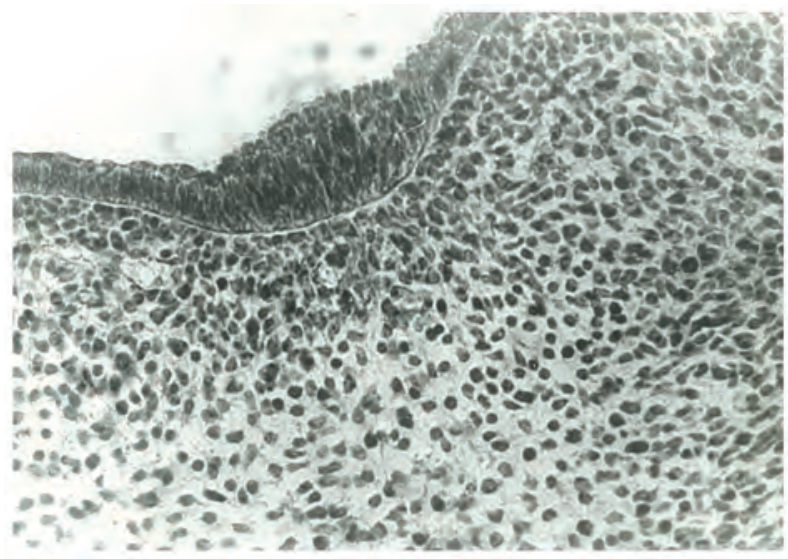

Fig. 1. Tooth bud protruding into the oral cavity without immersion growth into the underlying mesenchyme. 16-day-old fetal rat, experiment, staining with gallocyanin by Einarson method, $\mathrm{x} 200$

The enamel organ in unirradiated animals was flask-shaped, trapezoidal or in the form of a long and narrow finger-shaped outgrowth; it immersed in the 
mesenchyme and was connected with the dental lamina by means of a short neck of round and polygonal small hyperchromatic cells.

The enamel organ in the experiment was smaller, had a poorly defined neck, and reminded an irregular trapezium on the longitudinal section (Fig. 2). Its area was 2.79 times less than that in the control: $1.44 \pm 0.10$ (All the parameters of area in the text must be multiplied by $\left.10^{4}\right)$ and $4.02 \pm 0.66 \mu \mathrm{m}^{2}(p<0.001)$.

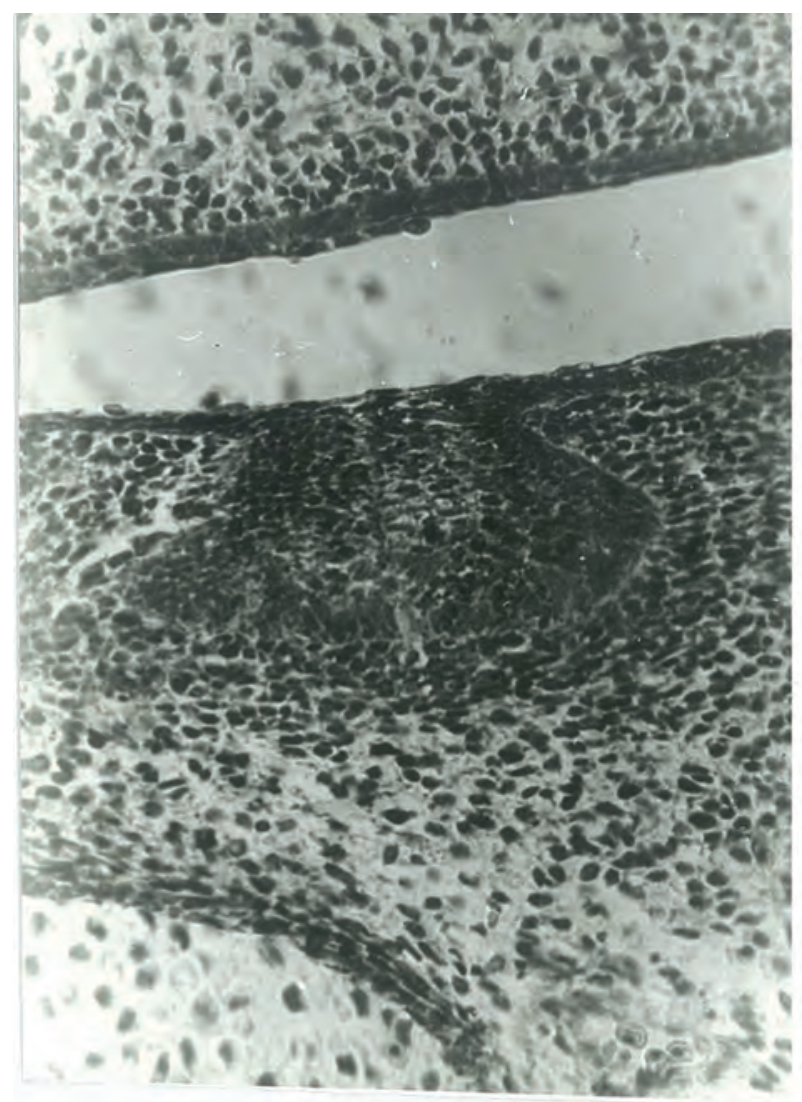

Fig. 2. Smaller enamel organ as compared with that one in the control (see Fig. 3), mitoses are almost lacking; poorly defined differentiation of the outer and inner enamel epithelium and the basement membrane, the lack of "concentric structures". 16-day-old fetal rat, experiment, staining with hematoxylin and eosin, $x 200$

In control animals, prismatic cells of the inner enamel epithelium were located on a well outlined basement membrane. The cells of the outer enamel epithelium were smaller, more hyperchromatic, almost spherical and did not form accurate layers (Fig. 3).

Scarce "concentric structures" "pressing into" the enamel organ pulp were found in the inner enamel epithelium (Fig. 4); these structures were almost not differentiated from those in the dental lamina. Probably these formations moved on cellular "conveyor" from the dental lamina to the enamel organ where they were partly included into the inner and outer enamel epithelium; "excessive" cell stratifying each

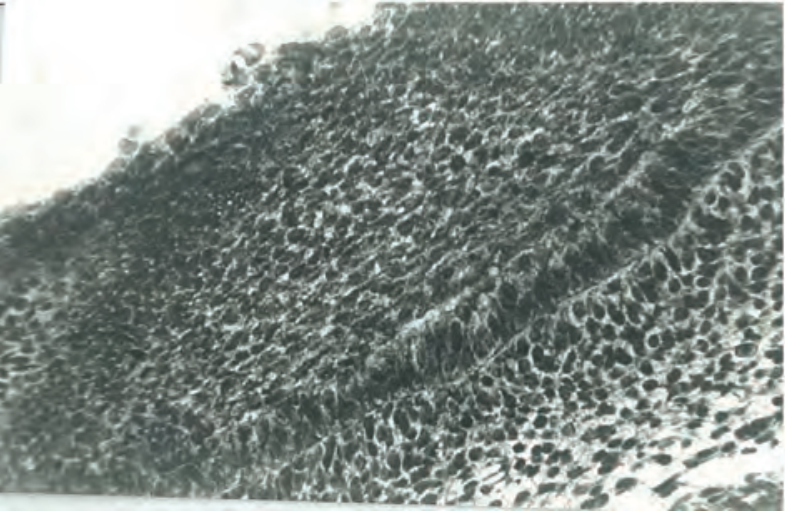

Fig. 3. General view of the enamel organ. Many mitoses are present. A clear differentiation of the inner enamel epithelium and the basement membrane. Denser accumu-

lation of dental papilla cells near the enamel epithelium.

16-day-old fetal rat, control, staining with hematoxylin and eosin, $x 200$

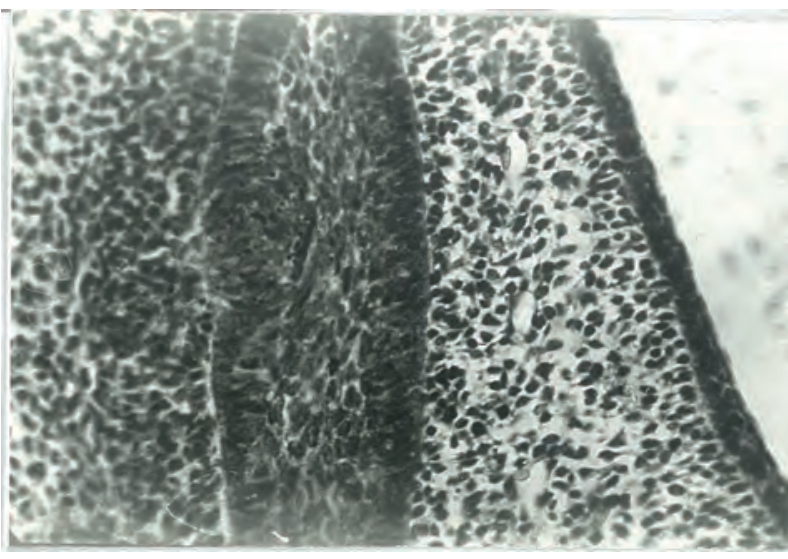

Fig. 4. Onion-like arrangement of cells with karyorrhexis ("concentric structure") in the inner enamel epithelium. 16-day-old fetal rat, control, staining with hematoxylin and eosin, $x 200$

other gradually disintegrated probably through apoptosis. It was proved by a marked karyorrhexis accompanied by the formation of small basophilic granules (chromatin fragments) and the lack of the mitosis in "concentric structures". The presence of such structures could be attributed to the intensive division of epithelial cells. This was confirmed by frequently occurring mitotic figures, often arranged in groups of four or more dividing cell elements in the inner enamel epithelium. Not only enhanced proliferation but, perhaps, lagging or the delay of cell differentiation were of certain importance in this process. There was no reason for considering the "concentric structures" to be reproduction centers on the basis of the above mentioned facts.

In the experiment the enamel epithelium was not clearly differentiated from the pulp. The mitotic index in the cells of the internal enamel epithelium was 
$8.91 \pm 2.96 \%$, in the control it was $20.88 \pm 1.69 \%$ $(p<0.05), 2.34$ times decrease in the experiment. The number of cell layers in the experimental rats was by 1.61 times less than in the control: $2.30 \pm 0.18$ and $3.70 \pm 0.39(p<0.01)$. The thickness of the inner enamel epithelium in the experiment and in the control was $24.99 \pm 1.51$ and $46.17 \pm 3.84 \mu \mathrm{m}(\mathrm{p}<0.001)$, a difference of 1.85 times. The thickness of the outer enamel epithelium was 1.84 times lower in the experimental animals in comparison with controls: $25.26 \pm 1.56$ and $46.44 \pm 4.80 \mu \mathrm{m}(\mathrm{p}<0.001)$.

In the control animals the enamel organ pulp consisted mainly of fusiform cells located a little more loosely than the cells of peripheral layers, but due to their large hyperchromatic nuclei, narrow membrane of cytoplasm, anastomoses could not be detected between them. Mitoses are frequent. The intermediate layer in the pulp was almost not outlined. In the experimental fetuses the enamel organ pulp seemed denser; it was formed by more hyperchromatic, closely adjoining to each other polygonal and fusiform cells. Among them many small basophilic granules occurred due karyo- and cytorrhexis (Fig. 5). Through the "gaps" in the inner enamel epithelium the cells of the pulp enamel organ were adjoining to the basement membrane for a distance of 20-30 $\mu \mathrm{m}$.

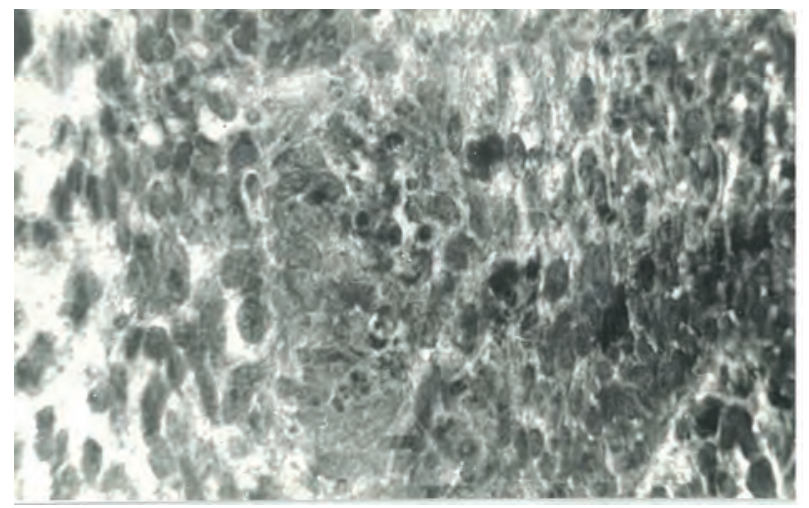

Fig. 5. Karyorrhexis in the cells of the enamel organ pulp, lacking mitoses, poor differentiation of the inner enamel epithelium from the pulp. 16-day-old fetal rat, experiment, staining with hematoxylin and eosin, x600

Clear borders between the cells of these "gaps" and the inner enamel epithelium were not detected. The mitotic index of the enamel organ pulp cells in the experiment and in the control was $10.88 \pm 0.99$ and $41.09 \pm 0.94 \%$ respectively $(p<0.001), 3.78$ times decrease in the experiment. The pulp area in the experimental fetuses was 2.05 times lower than that of the controls: $0.66 \pm 0.08$ and $1.35 \pm 0.20 \mu \mathrm{m}^{2}(p<0.01)$

Unirradiated animals had a clear thin basement membrane throughout the border between the epithelium and mesenchyme. Under the microscope (x 200) it looked as a shiny oxyphilic stria separated by a clearer space from the mesenchyme of the same thickness. In the experiment, the basement membrane was unevenly thickened. In these areas silver granules and slightly wavy thin fragments of argyrophil fibers lying against a lucid almost colorless background were found at impregnation (Fig. 6). The basement membrane was gradually gaining typical appearance; a thin impregnated with silver dark stria remained but it disappeared within some time. Owing to epithelium cells, frequently together with nuclei, invaginating into mesenchyme, the border between them was uneven as though serrated. All these changes may be sometimes revealed on the same section of tooth germ. Only a narrow clearer space was rarely seen between the epithelial cells and connective ones.

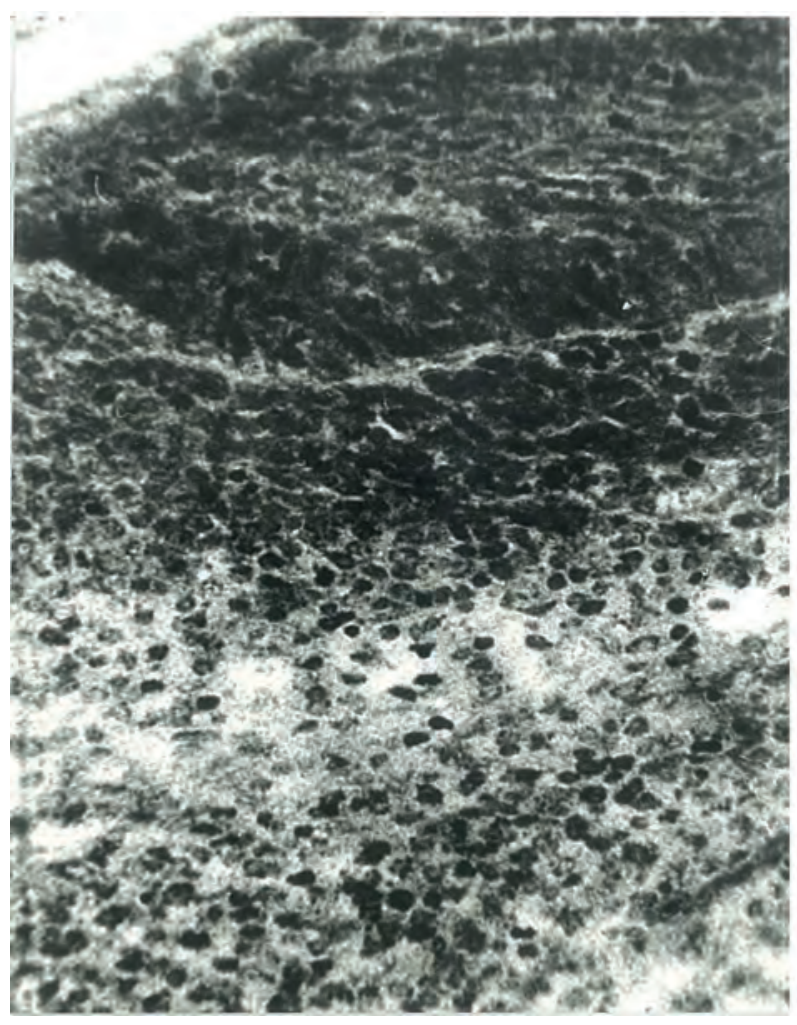

Fig. 6. Argyrophilic granules and thin fibers on a colorless thickened basement membrane of the enamel organ and between mesenchymal cells.

16-day-old fetal rat, experiment, impregnation with silver nitrate by Bilshovsky (H. Berlov's modification), x200

In the inner enamel epithelium large mesenchymal cells formed a solid dense cluster - dental papilla. There was no clear-cut border observed between it and the rest of the loose mesenchyme formed by clear-stained fusiform and stellate cells (dental sac). In the dental papilla of irradiated animals predominated large cells with big hyperchromatic nuclei. There were many fragments of chromatin in it. The experimental mitotic index in the dental papilla cells 
was 5.05 times lower than the control one: $2.99 \pm 0$ and $15.10 \pm 0.65 \%(p<0.001)$. The number of cell layers in the experiment was $6.05 \pm 0.34$, in the control it was $11.33 \pm 0.99(p<0.001), 1.87$ times difference. Its length was $47.32 \pm 2.00$ and $50.24 \pm 2.97 \mathrm{Mm}$, respectively ( $p>0.05), 1.06$ times decrease in the experiment. The experimental dental papilla was of a smaller size. Its area was 1.91 times lower than the control index: $2.04 \pm 0.13$ and $3.90 \pm 0.61 \mathrm{~mm}^{2}(p<0.05)$.

When impregnated with silver nitrate, thin fragments of argyrophilic fibers were detected only between the dental papilla cells, but the collagen or elastic fibers in the tooth germs were not found.

On staining by means of Einarson method the content of nucleic acids in all tooth germ cells in the control group could be scored 4-5 points, it being 3-4 points in the pulp only. In the experimental group an average 1 point decrease of these indices was observed.

A sharp suppression of the mitotic activity of tooth germ cells in the experiment was noted. So, general mitotic index in the experiment was $7.61 \pm 1.32 \%$, in the control group it was $25.84 \pm 0.45 \%(p<0.001)$. The proliferative activity decreased by 3.40 times after the exposure to low doses of ionizing radiation. Its sharpest decrease was noted in dental papilla cells. The total number of cell layers in tooth germs of the experimental rats was 1.97 times lower than in the controls: $10.35 \pm 0.65$ and $20.37 \pm 1.59(p<0.05)$.
The maximum difference here is related to the dental lamina.

We have not found in the available literature scientific papers on morphology on the effect of low doses of ionizing radiation on odontogenesis in experimental animals.

At present, assessing of the influence of «low doses» ionizing radiation have three opposite points of view. Some researchers point to the increased danger of «low doses», other reject any features of their effects and others indicate the existence of radiation hormesis, that is, the positive influence of ionizing radiation [15]. We believe that small doses of ionizing radiation damage the cells of the tooth germs.

Conclusion. So low doses of ionizing radiation did not interfere with the genetically determined odontogenesis process in 16-day-old fetal rats, but they significantly reduced the proliferative activity of the cells. This, in turn, resulted in the decrease in the size, number of cell layers, shape change, delay and impairment of tooth germ differentiation, lack of "concentric structures", their description hasn't been found in the literature.

Prospects of further researches. We see prospects for further research in the study of the effect of low doses of ionizing radiation on odontogenesis in experimental animals at later stages of their development.

\section{References}

1. Yarminenko SP, Vayson AA. Radiobiologiya cheloveka i zhivotnykh [Radiobiology of humans and animals]. M.: Vysshaya shkola; 2004: 549 s. [Russian]

2. Koterov AN. Ot ochen' malyh doz do ochen' bol'shih doz radiacii: dannye po ustanovleniyu diapazonov i ih eksperimental'no-epidemiologicheskoe obosnovanie [From very small doses to very large doses of radiation: data on establishing ranges and their experimental and epidemiological justification]. Med radiologiya i radiac bezopasnost'. 2013; 58(2): 5-21. [Russian]

3. Kaste SC, Hopkins KP, Jenkins JJ. Abnormal odontogenesis in children treated with radiation and chemotherapy: imaging findings. Am J Roentgenol. 1994; 162(6): 1407-11.

4. Adkins KF. The effect of 1200r of X-radiation on dentinogenesis in the mandibular teeth of rats. Archs Oral Biol. 1967; 12(12): 1569-76.

5. Collett WK, Thonard JC. The effect of fractional radiation on dentinogenesis in the rat. J Dent Res. 1965; 44(1): 84-90.

6. English JA, Tullis JL. Oral manifestations of ionizing radiation. I Oral lesions and effect on developing teeth of swine exposed to 2000 kv total body X- irradiation. J Dent Res. 1951; 30(1): 33-52.

7. Karlson B. Osnovy jembriologii po Pjettenu. [Patten's foundations of embryology]. M: Mir; 1983. Vol 2: 117-25. [Russian]

8. Hjem A, Kormak D. Gistologija [Histology]. M: Mir; 1983. Vol 4. 244 s. [Russian]

9. Falin LI. Gistologija i jembriologija polosti rta i zubov [Histology and embryology of the oral cavity]. M: Medgiz; 1963. 219 s. [Russian]

10. Cheshko NN. Metodika issledovanija odontogeneza [Methods of investigation of odontogenesis]. Zdravoohranenie Belarusi. 1993; 1: 35-6. [Russian]

11. Berlov GA. Tri modifikacii osnovnogo metoda Bil'shovskogo dlja impregnacii argirofil'nyh volokon $v$ celloidinovyh srezah [The Bilshovsky's method three modifications for impregnation of argyrophil fibers in celloidin-embedded specimens]. Arh Patologii. 1956; 18(2): 124-5. [Russian]

12. Kazantseva IA. Patologija mitoza $v$ opuholjah cheloveka [Tumor mitosis pathology in the human organism]. Novosibirsk: Nauka; 1981. 144 s. [Russian] 
13. Mel'nichenko JeM, Cheshko NN, Berlov HA, Rubenchik AJa, Nedz'ved' AM, Shevchuk TA. Morfometrija izmenenij odontogeneza u krys, vyzvannyh malymi dozami ionizirujushhej radiacii [Morphometric changes in rats odontogenesis caused by low dose ionizing radiation]. Zdravoohranenie. 1997; 10: 19-21. [Russian]

14. .Golenova IA. Osnovy medicinskoj statistiki s elementami vysshej matematiki: ucheb. posobie [Fundamentals of medical statistics with elements of higher mathematics: textbook]. Vitebsk: VGMU; 2017. 362 s. [Russian]

15. Hoshi M, Saimova AZh. Problema v ocenke effektov oblucheniya "malymi dozami" ioniziruyushchego izlucheniya. Obzor literatury [Problem in assessing the effects of radiation with «low doses». Review]. Nauka i zdravoohranenie [Science and Healthcare]. 2017; 2: 115-27. [Russian]

\section{УДК 616. 314: 575. 16: 616 - 092. 4 \\ ЕФЕКТ МАЛИХ ДОЗ ІОНІЗУЮЧОГО ВИПРОМІНЮВАННЯ НА ОДОНТОГЕНЕЗ У ПЛОДІВ ЩУРІВ \\ Чешко Н. М.}

Резюме. Мета - встановити вплив малих доз іонізуючого випромінювання на структуру зачатків зубів в онтогенезі і виявити характер можливих змін.

Дослідження проводили на безпорідних білих щурах стадного розведення. Вагітних самок в Інституті радіобіології НАН Білорусі піддавали впливу загального хронічного опромінення на установці "Гаммарид192/120" з потужністю експозиційної дози 110 мР/год з 1-ої доби вагітності до забору матеріалу на 16-у добу. Поглинена доза для плодів склала 0,38 Гр.

Інша група вагітних самок (контроль) містилася в стандартних умовах віварія. Контрольних тварин не опромінювали. Вагітних самок щурів обезголовлювали під хлороформним наркозом. Плоди щурів були витягнуті з матки і декапітовані.

Матеріал (голови плодів) фіксували в 10\%-ному розчині нейтрального формаліну і фіксували в парафіні за загальноприйнятою методикою. Сагітальні "серійно-вибіркові" зрізи фрарбували гематоксиліном і еозином, пікрофуксином за Ван-Гізоном, нуклеїнові кислоти виявляли галоціаніном за методом Ейнарсона, еластичні волокна -за Хартом, аргірофрільні - за Більшовським в модифікації Г. А. Берлова.

Проліферативну активність клітин визначали за методикою І. А. Казанцевої. Підраховували також кількість клітинних шарів. За допомогою системи аналізу зображень "Bioscan-AT" методом контурних вимірювань визначали площу і товщину структур зубних зачатків.

Малі дози іонізуючої радіації, хоча і не порушували генетично запрограмованого ходу одонтогенезу у 16-добових плодів щурів, значно знижували проліферативну активність клітин. Хронічне опромінення викликало 3-кратне зниження мітотичної активності клітин зачатків зубів у 16-добових плодів щурів. Це, в свою чергу, вело до зменшення розмірів, кількості клітинних шарів, зміни форми, затримки, порушення диференціювання зачатків зубів, відсутності «концентричних структур», опис яких ми не зустріли в літературі.

Таким чином, малі дози іонізуючої радіації не порушували генетично запрограмованого ходу одонтогенезу, але викликали ряд змін, які можуть зіграти негативну роль на подальших етапах розвитку зубів і в постнатальному періоді.

Ключові слова: одонтогенез, іонізуюча радіація, малі дози, щур.

Удк 616. 314: 575. 16: 616 - 092. 4

\section{ЭФФЕКТ МАЛЫХ ДОЗ ИОНИЗИРУЮЩЕГО ИЗЛУЧЕНИЯ \\ НА ОДОНТОГЕНЕЗ У ПЛОДОВ КРЫС \\ Чешко Н. $H$.}

Резюме. Цель - установить влияние малых доз ионизирующего излучения на структуру зачатков зубов в онтогенезе и выявить характер возможных изменений.

Исследование проводили на беспородных белых крысах стадного разведения. Беременных самок в Институте радиобиологии НАН Беларуси подвергали воздействию общего хронического облучения на установке «Гаммарид-192/120» с мощностью экспозиционной дозы 110 мР/4 с 1-х суток беременности до забора материала на 16-е сутки. Поглощенная доза для плодов составила 0,38 Гр.

Другая группа беременных самок (контроль) содержалась в стандартных условиях вивария. Контрольных животных не облучали. Беременных самок крыс обезглавливали под хлороформным наркозом. Плоды крыс были извлечены из матки и декапитированы.

Материал (головы плодов) фриксировали в 10\%-ном растворе нейтрального формалина и заключали в парафин по общепринятой методике. Сагиттальные «серийно-выборочные» срезы окрашивали 
гематоксилином и эозином, пикрофуксином по Ван-Гизону, нуклеиновые кислоты выявляли галлоцианином по методу Эйнарсона, эластические волокна - по Харту, аргирофильные - по Бильшовскому в модификации Г.А. Берлова.

Пролиферативную активность клеток определяли по методике И.А. Казанцевой. Подсчитывали также количество клеточных слоев. С помощью системы анализа изображений «Bioscan-AT» методом контурных измерений определяли площадь и толщину структур зубных зачатков.

Малые дозы ионизирующей радиации, хотя и не нарушали генетически запрограммированного хода одонтогенеза у 16-суточных плодов крыс, значительно снижали пролиферативную активность клеток. Хроническое облучение вызывало 3-кратное снижение митотической активности клеток зачатков зубов у 16-суточных плодов крыс. Это, в свою очередь, вело к уменьшению размеров, количества клеточных слоев, изменению формы, задержке, нарушению дифференцировки зачатков зубов, отсутствию «концентрических структур», описание которых мы не встретили в литературе.

Таким образом, малые дозы ионизирующей радиации не нарушали генетически запрограммированного хода одонтогенеза, но вызывали ряд изменений, которые могут сыграть отрицательную роль на дальнейших этапах развития зубов и в постнатальном периоде.

Ключевые слова: одонтогенез, ионизирующая радиация, малые дозы, крыса.

The authors of this study confirm that the research and publication of the results were not associated with any conflicts regarding commercial or financial relations, relations with organizations and/or individuals who may have been related to the study, and interrelations of coauthors of the article.

Стаття надійшла 31.03.2020 p. Рекомендована до друку на засіданні редакційної колегії після рецензування 